\title{
Effect of Seed Treatment of Fungicides and Biocides against Spot Blotch of Wheat Caused by Bipolaris sorokiniana
}

\author{
Sunil Kumar ${ }^{1}$, Virendra Kumar ${ }^{2 *}$, Prem Naresh ${ }^{1}$, ${\text { Ramesh } \operatorname{Singh}^{1} \text { and S.K. Biswas }}^{1}$ \\ ${ }^{1}$ Department of Plant Pathology, C.S Azad University of Agriculture and Technology, \\ Kanpur-208002, India \\ ${ }^{2}$ Swami Vivekanand University Sagar (M.P.) 470003, India \\ *Corresponding author
}

\section{Keywords \\ Spot blotch, \\ Fungicide, \\ Biocides, Seed treatment Wheat and Bipolaris sorokiniana \\ Article Info \\ Accepted: \\ 10 December 2018 \\ Available Online: \\ 10 January 2019}

\section{A B S T R A C T}

Spot blotch caused by Bipolaris sorokiniana is the most devastating in India and several other countries. The disease also seed, soil, air borne in nature therefore seed were play role in disease development. Seed treatment is a simple and first step of disease management in seed borne diseases and methods can reduces disease intensity of wheat. In seed treatment out of nine fungicide with different concentrations i.e. Raxil 060FS, Trifloxystrobin 500SC, Tebuconazole 2\% DS, Trifloxystrobin + Tebuconazole 080 FS, Nativo (Trifloxystrobin 25\% + Tebuconazole 50\%) 75 WG, Flint (Trifloxystrobin) 75 WG, Vitavax, Neemexecel and Bioagent (T. harzianum) have been revealed that the seed treatment with fungicides and biocides significantly increased the germination percentage of wheat seed over the control except Nativo $75 \mathrm{WG}$ and Trifloxystrobin + Tebuconazole 080 FS. In blotter paper method, The maximum germination with 100 per cent was recorded in the treatment of Trichoderma viride followed by Raxil 98.64\%, Tebuconazole $2 \%$ DS 98.24 per cent and vitavax 96.00. Seed treatment with neem product (neemexel) gave the superior result $(100 \%)$ over the control but inferior to other treatment and in regarding growth parameter, shoot length of wheat seedling with Trichoderma viride was best showing 85.69 per cent increase over control followed by Raxil060FS $(76.92 \%)$. The rest of the treatment were also showing increased trend of plant growth but not at par with T. viride. In case of glasshouse condition, the maximum with $99 \%$ seed germination was recorded in the treatment of Trichoderma viride followed by Raxil $98.50 \%$, Tebuconazole $2 \%$ DS $98.30 \%$, vitavax $92.40 \%$. The shoot length of wheat seedling was found maximum better under treatment with $T$. viride $(95.23 \%)$ representing on against $4.39 \mathrm{~cm}$ in control which was followed by $4.05 \mathrm{~cm}$ and $3.98 \mathrm{~cm}$ in Raxil 060FS and Vitavax treated plant respectively.

\section{Introduction}

Wheat (Triticum estivum L.) is important cereal food crop grown in India during Rabi season. It contributes major part to the food security system and provides more than 50 per cent calories to the people those are mostly dependent on wheat as a staple food (Sahai, 2009). India occupies the second place in term of production and area among the major wheat 
growing countries of the world after china. However, in the background of increasing population, the demand for wheat is increasing day by day, but production and productivity in India are remained stringent for last few decades which solely contributed due to some biotic and abiotic factors like, insect, diseases, weeds and nutritional deficiencies. Among the disease especially spot blotch caused by Bipolaris sorokiniana is the most devastating in India and several other countries. The disease adversely affect wheat yield particularly under late sown condition due to the practice of most popular rice - wheat cropping system. The pathogen affects all areal part of the plant and causes considerable losses in India.

Nema and Joshi (1971) reported that 3-20\% loss under different agro-climatic condition. The disease also seed, soil, air borne in nature therefore seed were play role in disease development. Seed treatment is a simple and first step of disease management in seed borne diseases and methods can reduces disease intensity of wheat. The management of disease can be done through cultural, chemical, biological and use of resistant variety. The cultivation of wheat with resistant verity is cheap and best method but resistant variety against the disease is scant. Cultural practices (sanitation, crop rotation and summer ploughing) prevented the development to spot blotch disease in the field condition but the method fail where it has already appeared in the standing crop. Biological control is easy and cheap method but bio agent are unfit for control of phyllosphere disease like spot blotch in standing crop (Singh, 2003). Hence, application of chemical is one of the most effective and widely recommended methods of disease management. But continuous uses of same chemical are not advisable which encourage development of resistant strain of among the pathogen. Therefore, there is need to change of chemical at a frequent interval of time. Hence, many new fungicides with biocides have been under taken to evaluate in the present investigation.

\section{Materials and Methods}

\section{Isolation of Bipolaris sorokiniana}

Naturally infected wheat leaf was collected from Student's Experimental Research Farm of Chandra Shekhar Azad University Agriculture and Technology, Kanpur. The disease portion of leaves were cut into $2 \mathrm{~mm}$. long pieces by sterilized blade and washed 3-4 times with sterilized water in order to remove the dust and other contaminant.

The pieces were dipped in $0.1 \% \mathrm{HgCl}_{2}$ for about 20-30 second then washed thoroughly in 3-4 times with distilled water to remove the remaining trace of $\mathrm{HgCl}_{2}$. The pieces were then transferred with the help of sterilized needle in sterilized Petri-dishes containing 2\% PDA medium previously poured aseptically and were incubated in B.O.D. at $25 \pm 1^{\circ} \mathrm{C}$. The pure culture was established by hyphal tip isolation method (Rangaswami, 2008). Fungus was identified by comprising its morphological character with old identified culture of Bipolaris sorokiniana and authentic description as given by Ellis (1971). The stock culture of $B$. sorokiniana were revived after every fort night and maintained through on PDA in sealed culture tubes at $5^{\circ} \mathrm{C}$ in refrigerator.

\section{Collection of fungicide and biocide}

The fungicides like Raxil 060FS, Trifloxystrobin 500SC, Tebeconazole 2\% DS, Trifloxystrobin + Tebeconazole 080 FS, Nativo (Trifloxystrobin 25\% + Tebeconazole 50\%) 75 WG, Flint (Trifloxystrobin) 75 WG and Vitavax and Neem based commercial formulation Neemexcel was also collected 
from local market at Rawatpur, Kanpur. Bioagent ( $T$. viride) was collected from Department of Plant Pathology C. S. Azad University of Agriculture and Technology, Kanpur for the present investigation.

\section{Preparation of bio-agent solution}

Seven days old culture was used to prepare homogenous suspension of bio-agent. The suspension containing conidia and mycelium bit was churned in a warning blender and strained with cheese cloth. The suspension containing approximately $10^{3}-10^{5}$ conidia was used for this study.

\section{Solution preparation of fungicides}

Different fungicides viz. Raxil 060FS, Trifloxystrobin 500SC, Tebuconazole 2\% DS, Trifloxystrobin + Tebuconazole 080 FS, Nativo (Trifloxystrobin $25 \%+$ Tebuconazole 50\%) 75 WG, Flint (Trifloxystrobin) 75 WG and Vitavax and Neemexcel of were tested in laboratory to find out the effect spore germination \& mycelial growth of pathogen. Exactly $0.03 \mathrm{mg}, 0.06 \mathrm{mg}, 0.12 \mathrm{mg}$ and 0.25 $\mathrm{mg}$ of six fungicides, were weighted and dissolved in water separately in $100 \mathrm{ml}$ of water to prepare $0.03,0.06,0.12$ and, $0.25 \%$ concentrations of fungicides.

Effect of fungicides as seed treatment on germination and growth parameter of wheat seedling

Seed treatment with fungicides, biocides and botanical are used to find out the germination of wheat seed. Seven fungicides viz. Raxil 060FS, Trifloxystrobin 500SC, Tebuconazole $2 \%$ DS, Trifloxystrobin + Tebuconazole 080FS, Nativo (Trifloxystrobin 25\% + Tebuconazole 50\%) 75 WG, Flint (Trifloxystrobin) $75 \mathrm{WG}$ and Vitavax and biocides like Sanjeevini (T. viride) and Neem execel@2.0 gm. / kg. of seeds and spore suspension of $T$. viride @ $100 \mathrm{ml}$. spore suspension / $100 \mathrm{~g}$ of seed were used to treat the seeds.

The required amount of fungicides solutions and seeds were taken in $250 \mathrm{ml}$ of conical flask separately and shaken well, then kept it for overnight and in the next day seed are dried in shades and used for the germination test and seedling growth by using blotter paper technique and glasshouse experiment.

\section{Blotter paper method}

The experiment on seed germination was conducted by blotter method technique using $90 \mathrm{~mm}$ dia. of the Petri plate. The bottom and slide wall of Petri plate was half way up with thick sterilized blotter papers which were moistened with sterilized water. Exactly 25 seeds treated with fungicides, bio pesticides were placed on blotter paper in each Petri plates, maintain equal distance to each other. Each treatment was replicated three times. One Petri plates was kept without seed treatment to serve as control. All Petri plates were kept in B.O.D. at $25^{\circ} \mathrm{C}$. The observations on the germination of seed and growth of seedling were measured by scale of every 24 hrs interval up to 7 days.

\section{Glass house condition}

For further confirmation to find out the effect of seed treatment on germination and growth of seedling the experiment was conducted at glass house complex, department of plant pathology. Wheat seeds variety K-9107 (Deva) was treated with fungicides and biocides and sown in $30 \mathrm{~cm}$ earthen pots separately which was previously filled with sterilized soil. Three replications were kept for each treatment and one pot without any seed treatment was kept as control.

\section{Results and Discussion}




\section{Blotter method}

The result present in the Table 1 indicated that seed treatment with fungicides and biocides significantly increased the germination percentage of wheat seed over the control except Nativo $75 \mathrm{WG}$ and Trifloxystrobin + Tebuconazole 080 FS. The maximum germination with 100 per cent was recorded in the treatment of Trichoderma viride followed by Raxil $98.64 \%$, Tebuconazole 2\% DS 98.24 per cent and Vitavax 96.00.

Table.1 Effect of seed treatment with fungicide and biocide on germination of wheat (Blotter paper method)

\begin{tabular}{|c|c|c|c|}
\hline S. No. & Seed Treatment & $\begin{array}{l}\text { Average germination } \\
\text { (out of 25) }\end{array}$ & $\begin{array}{c}\text { Germination } \\
\text { Percentage }\end{array}$ \\
\hline 1. & Rexil 060 FS & 24.66 & 98.64 \\
\hline 2. & Trifloxystrobin $500 \mathrm{SC}$ & 22.80 & 91.20 \\
\hline 3. & Trifloxystrobin+ Tebuconazole 080 FS & 20.70 & 82.80 \\
\hline 4. & Vitavax & 24.00 & 96.00 \\
\hline 5. & Flint (Trifloxystrobin) $50 \mathrm{WG}$ & 22.60 & 90.40 \\
\hline 6. & $\begin{array}{l}\text { Nativo (Trifloxystrobin } 25 \%+ \\
\text { Tebuconazole } 50 \% \text { ) } 75 \mathrm{WG}\end{array}$ & 21.10 & 84.40 \\
\hline 7. & Trichoderma viride & 25.00 & 100.00 \\
\hline 8 & Control & 25.00 & 100.00 \\
\hline
\end{tabular}

Table.2 Effect of seed treatment with fungicides and biocides on growth parameter of wheat seedling (Blotter paper method)

\begin{tabular}{|c|c|c|c|c|c|c|c|c|c|c|}
\hline \multirow[t]{2}{*}{ S. No. } & \multirow[t]{2}{*}{ Seed Treatment } & \multicolumn{7}{|c|}{ Growth of seedling up to 7 days } & \multirow[t]{2}{*}{ Mean } & \multirow{2}{*}{$\begin{array}{c}\% \text { increase } \\
\text { over Control }\end{array}$} \\
\hline & & 1 & 2 & 3 & 4 & 5 & 6 & 7 & & \\
\hline 1. & Rexil 060 FS & 0.65 & 1.20 & 2.35 & 4.63 & 7.05 & 8.62 & 11.5 & 5.14 & 76.92 \\
\hline 2. & Trifloxystrobin $500 \mathrm{SC}$ & 0.30 & 0.62 & 0.72 & 1.50 & 3.46 & 6.00 & 7.25 & 2.83 & 11.53 \\
\hline 3. & $\begin{array}{c}\text { Trifloxystrobin+ } \\
\text { Tebuconazole 080 FS }\end{array}$ & 0.25 & 0.58 & 0.70 & 0.90 & 2.10 & 5.33 & 5.00 & 2.12 & -23.07 \\
\hline 4. & Vitavax & 0.58 & 1.18 & 2.28 & 4.32 & 6.60 & 8.25 & 10.50 & 4.81 & 61.53 \\
\hline 5. & $\begin{array}{l}\text { Flint (Trifloxystrobin) } 50 \\
\text { WG }\end{array}$ & 0.29 & 0.60 & 0.68 & 1.60 & 3.50 & 6.20 & 7.65 & 2.93 & 17.67 \\
\hline 6. & $\begin{array}{c}\text { Nativo (Trifloxystrobin } 25 \% \\
+ \text { Tebuconazole } 50 \% \text { ) } 75 \\
\text { WG }\end{array}$ & 0.20 & 0.50 & 0.68 & 0.80 & 1.50 & 3.60 & 4.20 & 1.64 & -35.38 \\
\hline 7. & Trichoderma viride & 0.71 & 1.14 & 3.14 & 5.61 & 7.98 & 10.09 & 12.07 & 5.82 & 85.69 \\
\hline 8. & Neemexcel & 0.45 & 0.70 & 0.90 & 1.60 & 5.80 & 6.72 & 8.20 & 3.48 & 26.15 \\
\hline 9. & Tebuconazole $2 \%$ DS & 0.62 & 1.23 & 2.30 & 4.60 & 6.58 & 8.52 & 11.09 & 4.99 & 70.61 \\
\hline 10. & Control & 0.25 & 0.60 & 0.80 & 1.40 & 2.98 & 5.59 & 6.50 & 2.50 & \\
\hline 11. & Mean & 0.43 & 0.83 & 1.44 & 2.64 & 4.75 & 6.89 & 8.39 & & \\
\hline \multirow[t]{2}{*}{12.} & \multirow[b]{2}{*}{ C.D. at $5 \%(\mathrm{P}=0.05)$} & & $\mathbf{A}$ & & B & & $\mathbf{A} \times \mathbf{B}$ & & & \\
\hline & & & 0.12 & & 0.10 & & 0.32 & & & \\
\hline
\end{tabular}

Where, $\mathrm{A}=$ It indicate number of treatments, $\mathrm{B}=$ it indicate number of days.

Table.3 Effect of seed treatment with fungicides and biocides on germination of wheat in 
glasshouse condition

\begin{tabular}{|c|l|c|c|}
\hline S. No. & Seed Treatment & $\begin{array}{c}\text { Average germination } \\
\text { (out of 10) }\end{array}$ & $\begin{array}{c}\text { Germination } \\
\text { percentage }\end{array}$ \\
\hline $\mathbf{1 .}$ & Rexil 060 FS & 9.85 & 98.50 \\
\hline $\mathbf{2 .}$ & Trifloxystrobin 500 SC & 8.81 & 88.10 \\
\hline $\mathbf{3 .}$ & Trifloxystrobin+ Tebuconazole 080 FS & 8.42 & 84.20 \\
\hline $\mathbf{4 .}$ & Vitavax & 9.24 & 92.4 \\
\hline $\mathbf{5 .}$ & Flint (Trifloxystrobin) 50 WG & 8.89 & 88.9 \\
\hline $\mathbf{6 .}$ & Nativo (Trifloxystrobin 25\% & 8.20 & 82.0 \\
\hline & Tebuconazole 50\%) 75 WG & 9.90 & 99.0 \\
\hline $\mathbf{7 .}$ & Trichoderma viride & 9.20 & 92.0 \\
\hline $\mathbf{8 .}$ & Neemexcel & 9.83 & 98.30 \\
\hline $\mathbf{9}$ & Tebuconazole 2\% DS & 75.0 & 75.0 \\
\hline $\mathbf{1 0}$ & Control & & $\mathbf{5 . 1 4}$ \\
\hline & C.D. at 5\% (P=0.05) & & \\
\hline
\end{tabular}

Table.4 Effect of seed treatment with fungicide and biocides on growth parameter of wheat seedling under glasshouse condition

\begin{tabular}{|c|c|c|c|c|c|c|c|c|c|c|}
\hline \multirow[t]{2}{*}{ S. No } & \multirow[t]{2}{*}{ Seed Treatment } & \multicolumn{7}{|c|}{ Growth of seedling up to 7 days } & \multirow[t]{2}{*}{ Mean } & \multirow{2}{*}{$\begin{array}{c}\% \\
\text { increase } \\
\text { over } \\
\text { Control }\end{array}$} \\
\hline & & 1 & 2 & 3 & 4 & 5 & 6 & 7 & & \\
\hline 1. & Rexil 060 FS & 1.60 & 2.54 & 3.10 & 3.48 & 3.75 & 4.00 & 4.05 & 3.98 & 92.85 \\
\hline 2. & Trifloxystrobin $500 \mathrm{SC}$ & 0.90 & 1.50 & 2.22 & 3.12 & 3.27 & 3.50 & 3.70 & 2.96 & 76.19 \\
\hline 3. & $\begin{array}{l}\text { Trifloxystrobin+ } \\
\text { Tebuconazole } 080 \text { FS }\end{array}$ & 0.62 & 0.98 & 1.78 & 2.10 & 2.35 & 2.21 & 3.25 & 2.00 & 54.74 \\
\hline 4. & Vitavax & 1.48 & 1.88 & 3.00 & 3.10 & 3.30 & 3.50 & 3.98 & 3.49 & 89.52 \\
\hline 5. & $\begin{array}{l}\text { Flint (Trifloxystrobin) } \\
50 \mathrm{WG}\end{array}$ & 0.92 & 1.50 & 2.22 & 3.00 & 3.10 & 3.30 & 3.68 & 2.93 & 75.23 \\
\hline 6. & $\begin{array}{l}\text { Nativo (Trifloxystrobin } \\
25 \% \text { + Tebuconazole } \\
50 \% \text { ) } 75 \mathrm{WG}\end{array}$ & 0.50 & 0.96 & 1.45 & 1.95 & 2.20 & 2.10 & 3.22 & 1.76 & 53.33 \\
\hline 7. & Trichoderma viride & 1.86 & 2.78 & 3.22 & 3.50 & 3.85 & 4.00 & 4.10 & 4.39 & 95.23 \\
\hline 8. & Neemexcel & 1.02 & 1.66 & 2.60 & 3.00 & 3.20 & 3.50 & 3.70 & 3.18 & 76.19 \\
\hline 9. & Tebuconazole $2 \%$ DS & 1.69 & 2.52 & 2.78 & 3.10 & 3.40 & 3.90 & 4.00 & 3.96 & 90.47 \\
\hline 10. & Control & 0.50 & 0.80 & 1.20 & 1.40 & 1.60 & 1.88 & 2.10 & 1.35 & 0.00 \\
\hline 11. & Mean & 1.11 & 1.71 & 2.47 & 3.34 & 4.14 & 4.61 & 3.61 & & \\
\hline \multirow[t]{2}{*}{12.} & \multirow{2}{*}{ C.D. at $5 \%(P=0.05)$} & & A & & B & & $\mathrm{A} \times \mathrm{B}$ & & & \\
\hline & & & 0.12 & & 0.10 & & 0.33 & & & \\
\hline
\end{tabular}

Where $\mathrm{A}=\mathrm{It}$ indicate number of treatments $\mathrm{B}=$ it indicate number of days.

Biswas et al., (2008) also reported that seed treatment with biocides such as Trichoderma 
harzianum and $T$. viride provide good protection of seed against seed borne infection, resulting in enhanced germination and shoot and root length of paddy seeds

\section{Growth parameter}

The effect of seed treatment with the fungicides, biocides ( $T$. viride, neemexel) on shoot and root length of wheat seedling were studied in the laboratory condition by blotter paper (Table 2) and it was found that shoot lenth of wheat seedling with Trichoderma viride was best showing 85.69 per cent increase over control followed by result $(76.92 \%)$. The rest of the treatment were also showing increased trend of plant growth but not at par with $T$. viride. Singh and Saxena (1986) also selected 20 fungicides against $D$. sorokiniana in vitro when these were used as seed treatment and found that Thiram and Dithane Z-78 were given the best seedling emergence and control of root rots disease.

\section{Glass house experiment}

Effect of seed treatment also with fungicide and biocide on seed germination and growth of seedling. The maximum with $99 \%$ seed germination was recorded in the treatment of T. viride followed by Raxil $98.50 \%$, vitavax $92.40 \%$. Seed treatment with neem product (neemexcel) gave the good result with germination $92.00 \%$ under glass house condition (Table 3). Keyser et al., (2001), reported that Trifloxystrobin is a new fungicide which is very effective against the foliar disease of all cereals including wheat, especially due to its long lasting effect.

\section{Growth parameter}

The effect of seed treatment with the fungicides, biocides ( $T$. viride, neemexel) on shoot and root length of wheat seedling were studied under glass house condition. The result presented in the (Table 4) revealed that, the shoot length of wheat seedling was found maximum better under treatment with $T$. viride representing on against $4.39 \mathrm{~cm}$ in control which was followed by $4.05 \mathrm{~cm}$ and $3.98 \mathrm{~cm}$ in Rexil 060FS and vitavax treated plant respectively.

Stevanovic et al., (2009) also reported that significantly increased germination was found with the seed treatment by vitavax $200 \mathrm{FF}$ and Raxil 060-FS.

Singh et al., (2007) evaluated that vitavax200ws (Carboxin, 2.0, 2.5 or $3.0 \mathrm{~g} / \mathrm{kg}$ of seed), vitavax $75 \mathrm{wp}(2.5 \mathrm{~g} / \mathrm{kg}$ of seed), Thiram $75 \mathrm{ws}(3.0 \mathrm{~g} / \mathrm{kg}$ of seed $)$ as seed treatment against $B$. sorokiniana and Alternaria triticina and found that vitavax200 ws at all rates completely eradicated $B$. sorokiniana, and A. triticina. They also found that the enhancement of seedling vigor (root and shoot length), seed germination and highest yield were obtained from application of vitavax@3.0.gm.

\section{References}

Biswas S.K., Ved Ratan, Srivastava,S.S.L. and Singh Ramesh (2008). Influence of seed treatment with biocides and foliar spray with fungicides for management of brown leaf spot and sheath blight of paddy. Indian Phytopath. (61) 1: 55-59.

Ellis, M.B. (1971). Dematiaceaous hypomycetes, C.M.I., Kew, Surry, England, 608 pp.

Singh D.P., Chowdhary A.K. and Pankaj Kumar (2007). Management of losses due to seed borne infection of $B$. sorokiniana and Alternaria triticina in wheat using seed treatment with Vitavax 200WS. Indian J. of Agri. Sc. 77(2):101-103.

Singh, Chhidda (2003). Modern techniques of field crops raising. pp 46-58. Oxford 
and IBH Co. Ltd., New Delhi.

Stevavic, V.J. Inic, D.J. Vukovic, $\mathrm{S}$ and Grahovac, M. (2009). Influence of fungicides for seed treatment on germination of wheat. Biljni lekar (Plant Doctor) facility of Agriculture, Department for Environmental and Pant Protection, University of NOVI Sad, Serbia., 37(6): 626-633.

Keyser Gaury, F. and Lemaire, A. (2001). Trifloxistrobin a fungicides for treatment on vegetation of cereals. Phytoma. 542: 45-47.

Rangaswami, G. (2008). Diseases of crop plant in India. PHI Learning Pvt. Ltd,
New Delhi. pp165.

Nema, K.G. and Joshi, L.M. (1971). The spot blotch disease of wheat caused by Helmithosporium sativum. Proc. Second Int. Symp. Plant Path., I.A.R.I., New Delhi. Pp. 42.

Sahai, Suman (2009). Acknowledge the farmer as a cultivator, conserver and seed producer: The Hindu Survey of Indian Agriculture. Pp. 135.

Singh, D.V. and Saxena H.K. (1986). Chemical control of root rot and leaf blight of wheat caused by Drechslera sorokiniana and search for source of resistance. Indian J. Pl. Path., 3: 89-93.

\section{How to cite this article:}

Sunil Kumar, Virendra Kumar, Prem Naresh, Ramesh Singh and Biswas, S.K. 2019. Effect of Seed Treatment of Fungicides and Biocides against Spot Blotch of Wheat Caused by Bipolaris sorokiniana. Int.J.Curr.Microbiol.App.Sci. 8(01): 1223-1229.

doi: https://doi.org/10.20546/ijcmas.2019.801.129 